Review Article

\title{
OUTBREAK, EPIDEMIOLOGY, THERAPEUTICS AND PREVENTION OF CORONAVIRUS DISEASE- 2019: A REVIEW
}

\section{ZULFKAR LATIEF QADRIE1* ${ }^{*}$, SHAHID UD DIN WANI², SURYA PRAKASH GAUTAM², M. KHALID AHMED KHAN ${ }^{3}$}

${ }^{1}$ Department of Pharmacology, CT Institute of Pharmaceutical Sciences, CT Group of Institutions, Jalandhar, India, ${ }^{* 2}$ Department of Pharmaceutics, CT Institute of Pharmaceutical Sciences, CT Group of Institutions, Jalandhar, India, ${ }^{3}$ Assistant Drugs Controller, Drugs Control Department, Govt. of Karnataka, Bengaluru, Karnataka, India.

Email: dr.zulfikarqadrie@gmail.com,shahidpharma2013@gmail.com

Received: 12 Jun 2020, Revised and Accepted: 15 Aug 2020

\section{ABSTRACT}

The outbreak of pneumonia of unknown cause during December 2019 was reported from Wuhan City, Hubei province capital in China as its epicenter. Symptoms of pneumonia in several patients admitted to hospitals from Wuhan, China during December 2019. The sudden increase in the patients having the same symptoms, in due course the contributing means was isolated from the infected populace. In the present short report, we have summarized various public health measures, viz., early marking of the suspected patient, diagnosis, and supervision of the suspected cases that will help prevent Coronavirus disease in 2019. At the start, it was named as the 2019 novel coronavirus (2019-nCoV), and later it has been named Coronavirus disease 2019 (COVID-19) recently. Within a few weeks of a short period, the virus affected the other of China after Wuhan and later in two to three months, it is present in more than 140 countries around the globe and adding. As of 03 $3^{\text {rd }}$ August 2020 , there have been 17.6 million established cases worldwide, and 680, 894 deaths have been documented, with 11,460,074 recovered. Worldwide, multiple trails are going on with the hope to find the treatment and some have positive results. On the other hand, because no vaccine is offered, the precautionary methods are the best way to fight the virus.

Keywords: WHO, Coronavirus, Polymerase chain reaction, COVID-19, Antiviral therapy

(c) 2020 The Authors. Published by Innovare Academic Sciences Pvt Ltd. This is an open access article under the CC BY license (http://creativecommons.org/licenses/by/4.0/) DOI: http://dx.doi.org/10.22159/ijcpr.2020v12i5.39755. Journal homepage: https://innovareacademics.in/journals/index.php/ijcpr

Speedy peer review was done as the subject of the manuscript was related with pandemic.

\section{INTRODUCTION}

Outbreaks of pneumonia of unknown cause during December, 2019 were reported from Wuhan City, Hubei province capital in Republic of China was the epicenter. The Chinese Scientist had breakthrough by $7^{\text {th }}$ January 2020 , isolated Novel Coronavirus, which affected the Chinese populous and named as severe acute respiratory syndrome coronavirus 2 (SARS-CoV-2; formerly recognized as 2019-nCoV) [1, 2], presently nominated coronavirus disease 2019 (COVID-19) in February, 2020 by WHO [3].

An international threat to public health lands in emergency situation by COVID-19. Approximately, $15 \%$ of the effected population is the severe form [4]. Right now, specific, effective, proven, pharmacological treatment is not available world. Traditional immuno modulant drug, Chloroquine which is used in the treatment of malaria, reduces viral replication in other infections, as well as the Severe Acute Respiratory Syndrome (SARS-associated coronavirus $(\mathrm{CoV}))$ and Middle East Respiratory Syndrome (MERS-CoV) recommended by In vitro studies [5-7].

An data examination of twenty-two studies, exposed that human coronaviruses like SARS, MERS or endemic human coronaviruses ( $\mathrm{HCoV}$ ) can sustain for up to $9 \mathrm{~d}$ on the non-living surfaces like metal, glass or plastic, nevertheless can be professionally inactivated by disinfection of surfaces by means of ethanol (62-71\%), hydrogen peroxide $(0.5 \%)$ or sodium hypochlorite $(0.1 \%)$ within 1 minute of time [8].

\section{Epidemiology}

On August 03, 2020, globally confirmed cases have reached to 17.6 million cases and more than 680, 894 deaths registered as per WHO; all related confirmed cases $(37.92 \%)$ and deaths (43.7\%) were due to COVID-19 from USA. In view of the fact, COVID-19 first case was reported from the epicenter "Wuhan". Officially, China was classified as an extremely high danger zone for COVID-19 by World Health Organization [9].

Shorter timelines have been reported by multiple cases, with the incubation phase of the germ was considered to be fourteen days. The calculated mean of incubation phase has to be $4 \mathrm{~d}$ with an inferior interquartile array of $2 \mathrm{~d}$ and a superior interquartile array of $7 \mathrm{~d}$ were suggested by well-known study of Guan et al. The most frequent finding in their study were ground-glass opacity on CT (56.4\%) [10], they establish fever in $43.8 \%$ on admission and during hospitalization $88.7 \%$. In around $67.8 \%$ of patients, cough was common symptom. The definite cases were in adults involving age 30 to 79 y was found $87 \%$, data provided by the Chinese Center for Disease Control and Prevention. With an increase in ages, the mortality and case fatality rate increased, $8 \%$ was the fatality rate in patients aged among 70 to $79 \mathrm{y}$, that aged $80 \mathrm{y}$ or more, $15 \%$ was fatality rate [4].

The children presented with fever ( $80 \%)$, while cough was seen in $60 \%$ showed during the study of cases [11]. The mild symptoms were presented in all children and all improved. The study suggests that the confirmed patients had lingering virus shedding in the respiratory system and gastrointestinal system through feces, even in their restorative stages. One more study concerned 9 contaminated infants (1-11 mo). Four out of 9 infants presented with fever, 1 patient without any signs and symptoms, tested positive for COVID-19. All 9 infants neither need mechanical ventilator nor intensive care unit admission [12].

\section{Tests for COVID-19}

Samples for the COVID-19 are taken from the upper respiratory tract meant for the test. Polymerase chain reaction (PCR) is acknowledged out to recognize their viral RNA. The diagnosis of COVID-19 is confirmed if the test is positive. Negative results with a powerful feeling, viz., medical symptoms or exposure, repeat the test 
for the samples taken from other site of the upper respiratory tract is becoming mandatory $[13,15]$. The white blood cell count can vary for persons affected with COVID-19. The conditions like Leukocytosis, Lymphopenia, and Leukopenia have been reported, even though lymphopenia appears more frequently [16, 17]. On admittance, many infected persons with the symptoms like pneumonia comprise regular serum pro-calcitonin level; although, in them demanding ICU support, they are further possibly high. Tomography results- Chest assessed tomography (CT) in infected persons nearly usually exhibits integrative deformity, constant by viral pneumonia [18]. An oropharyngeal swab can be obtained other than it is not vital; if collected, it must be positioned in a similar bottle as the nasopharyngeal sample. An oropharyngeal swab is a satisfactory option if nasopharyngeal swabs are not available [19]. If early testing is negative, although the notion for COVID-19 remains, then the WHO proposes further sampling \& testing from other respiratory tracts [20]. The accurateness and analytical ideals of SARS-CoV-2 testing have not been scientifically assessed. Coinfection with SARS-CoV-2 and additional respiratory viruses, together with influenza, has been reported, and this possibly influences the administrative resolutions.

\section{Therapeutics of COVID-19}

To assist patients amid with severe symptoms of COVID-19 around the globe, several antiviral regimens are being prescribed to infected patients. In some clinical trials, lopinavir and ritonavir have been used. The viral loads decreased significantly, helped the patients to improve clinically, suggested a report from Lim et al., Wang et. al, admitted 4 patients with COVID-19 for the study in Shanghai, City of China, improved with the collective treatment of lopinavir and ritonavir therapy $[21,30]$. Confirmed cases of COVID-19 were hospitalized and prescribed with the combined antiviral therapy of lopinavir and ritonavir in Singapore. Some patients showed recovery progress in the signs and symptoms caused by COVID-19; nausea, vomiting or diarrhea was reported in 4patients and disarranged liver serum enzymes were reported by 3 patients [22]

Drugs like remdesivir, peptide (EK1), neuraminidase inhibitors, chloroquine, and arbidol have been recommended as several other treatment options available [23]. Multiple research teams around the globe are trying to investigate a possible vaccine for COVID-19. The possible preventive target will be the spike proteins in the viral infectivity and pathogenesis [24]. The Glucocorticoids must not be employed in infected persons with symptoms like pneumonia until new signs for e.g. aggravation of chronic obstructive pulmonary disorder $[25,26]$. Assistance with the oxygen treatment of high-flow nasal oxygen (HFNO) must be utilized only in preferred patients amid hypoxemic respiratory collapse. Comparing typical oxygen treatment, the HFNO decreases the requirement for cannulation.
Mechanized ventilation is the major encouraging management for significantly infected patients $[27,28]$.

\section{Prevention of COVID-19}

Multiple steps are recommended for the prevention of the transmission and risk of COVID-19 by Centers for Disease Control and Prevention (CDC). Frequent hand washing, which lasts at least for 20 seconds with use of any type of soap and clean water is recommended. An alternative to clean the hands are sanitizers with an alcohol $(60 \%)$. Also make it clear to the general public, that avoidance of touching to mucosal surfaces viz., the mouth and the nose with hands that are untidy or not clean. Seek appropriate medical consultation for showing any symptoms to COVID-19. To break the chain of human-human transmission, affected people should have minimum or zero exposure to other healthier people and while coughing and sneezing wrap their noses and mouth with tissue papers or handkerchiefs to avoid the release of virus in air or any other surface. The people with symptoms are advised to wear face masks. The doctors, nurses and the people who are having close contact with the confirmed cases of COVID-19 are advised to have frequent disinfection and cleaning as they are at high risk of getting contaminated [29]. Currently, no vaccine has been developed, and the most excellent prevention is to circumvent contact with the virus [31]. In organize to attain this objective; the important procedures can be pursued as displayed in fig. 1 [32].

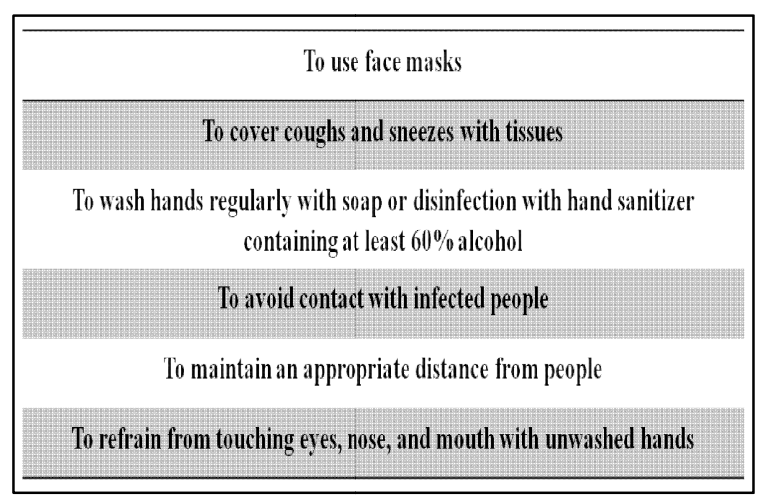

Fig. 1: Several measures to be pursued to contain and prevent COVID-19

\section{Planned objectives given by WHO's}

The strategic objectives by WHO are shown in fig. 1. They indicate clear instruction for the populace around the globe.

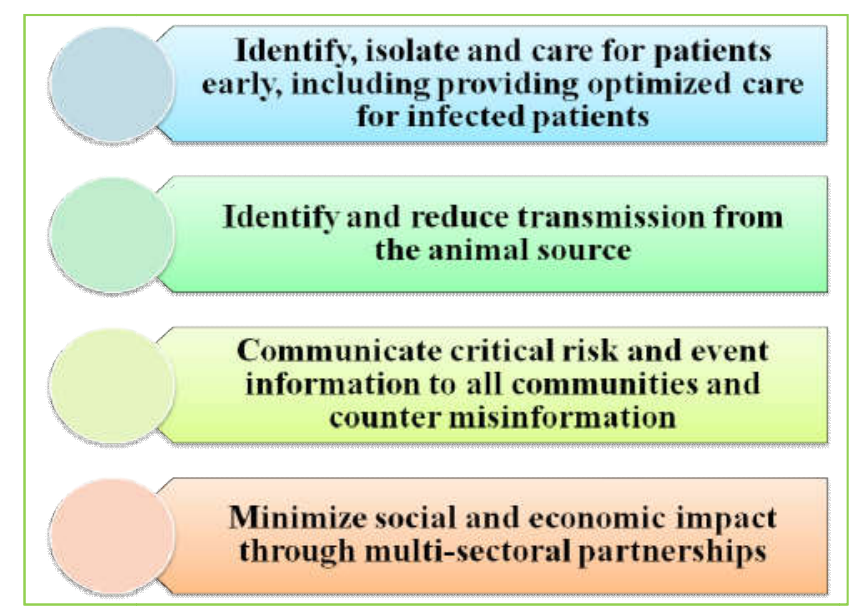

Fig. 2: Strategic objectives by WHO 
As per the WHO guidelines, it can be achieved through an amalgamation of public health measures, viz., early marking of suspected patient, diagnosis and supervision of the suspected cases, marking and tracking of the contacts with suspected or confirmed case, infection avoidance and organize the health care facilities, execution of health care procedures for travelers, raising awareness among the populace and discuss the risk assessments.

\section{Future perspective}

The COVID-19 epidemic is exhibiting to be an unmatched catastrophe, particularly in the most disturbing nations comprising China, Italy, Iran, USA, Brazil, and India in all facets, mainly wellbeing, community \& financial. It is too untimely to predict any pragmatic development; however, globally, it will have powerful implications. Moreover, to this low positive implication, if the preventive procedures will be carried out, we may list a lesser prevalence of healthiness-associated disorders that remains important grounds of mortality [33].

\section{CONCLUSION}

The present review imparts a comprehension into the COVID-19 present state and characterizes a depiction of the existing condition of the skill in provisions of community fitness influence, the pathophysiology \& medical demonstrations, finding, case supervision, disaster reaction, and awareness. The spread of COVID19 across the globe is at an alarming rate. People with comorbidities like high blood pressure, cardiovascular disorders, cerebrovascular disorders, diabetes, immuno-compromised patients and elderly people/geriatrics are most susceptible to the mortal repercussions of the COVID-19. Some antiviral regimes have showing promising results, but at present/in hand no confirmed treatment and cure for virus andstill work on vaccine is going on and has been not yet developed. At the time, with proper precautionary procedures, the COVID-19 can be restricted and the populace protected. Simply once this epidemic ends, one will be able to evaluate the healthiness, public and financial impact of this worldwide catastrophe and we must be able to find out lessons particularly in terms of community and worldwide health for any future pandemics.

\section{ACKNOWLEDGEMENT}

Authors thank The Director, CT Institute of Pharmaceutical Sciences, Jalandhar and The Management, CT Group of Institutions, Jalandhar for their continuous support and motivation.

\section{FUNDING}

$\mathrm{Nil}$

\section{AUTHORS CONTRIBUTIONS}

Qadrie ZL and Wani Shahid UD envisaged the initiative and drafted the manuscript. All the authors reviewed the literature, vitally revised, and agreed the final description prior to submission.

\section{CONFLICT OF INTERESTS}

The Author(s) declare(s) that there is no conflict of interest.

\section{REFERENCES}

1. Phelan AL, Katz R, Gostin OL. The novel coronavirus is originating in Wuhan, China: challenges for global health governance. JAMA 2020;323:709-10.

2. Gorbalenya AE, Baker SC, Baric RS, Groot RJ, Haagmans BL, Neuman BW, et al. The species severe acute respiratory syndrome-related coronavirus: classifying 2019-nCoV and naming it SARS-CoV-2. Nat Microbiol 2020;5:536-44.

3. Chan J, Ng C, Chan Y, Mok T, Lee S, Chu S, et al. Short term outcome and risk factors for adverse clinical outcomes in adults with the severe acute respiratory syndrome (SARS). Thorax 2003;58:686-9.
4. Wu Z, McGoogan JM. Characteristics of and important lessons from the coronavirus disease 2019 (COVID-19) outbreak in China. JAMA 2020;323:1239-42.

5. Savarino A, Boelaert JR, Cassone A, Majori G, Cauda R. Effects of chloroquine on viral infections: an old drug against today's diseases? Lancet Infectious Diseases 2003;3 :722-7.

6. Colson P, Rolain JM, Raoult D. Chloroquine for the 2019 novel coronavirus SARS-CoV-2. Int J Antimicrob Agents 2020;55:105923.

7. World Health Organization. Prioritizing diseases for research and development in emergency contexts 2020. Available from: https://www.who.int/activities/prioritizing-diseases-forresearch-and-development-in-emergency-contexts [Last accessed on 02 Mar 2020]

8. Kampf G, Todtb D, Pfaender S, Steinmann E. Persistence of coronaviruses on inanimate surfaces and their inactivation with biocidal agents. J Hospital Infection 2020;104:246-51.

9. World Health Organization. Novel coronavirus (2019-nCoV) situation report 195 . Available from: https://https:// www.who.int/docs/default-source/coronaviruse/situationreports/20200802-covid-19-sitrep-195.pdf?sfvrsn=5e5da0c5_2 [Last accessed on 03 Aug 2020]

10. Guan W, Ni Z, Hu Y, Liang W, Ou C, He J, et al. Clinical characteristics of coronavirus disease 2019 in China. N Engl J Med 2020;382:1708-20

11. Cai J, Xu J, Lin D, Yang Z, Xu L, Qu Z, et al. A case series of children with 2019 novel coronavirus infection: clinical and epidemiological features. Clin Infectious Diseases 2020. DOI:10.1093/cid/ciaa198

12. Wei M, Yuan J, Liu Y, Fu T, Yu X, Zhang Z. Novel coronavirus infection in hospitalized infants under $1 \mathrm{y}$ of age in China. JAMA 2020;323:1313-4

13. Centers for Disease Control and Prevention. Persons evaluated for 2019 novel coronavirus United States; 2020. Available from: https://www.cdc.gov/mmwr/volumes/69/wr/mm6906e1.htm?s_ cid=mm6906e1_x [Last accessed on 11 Mar 2020]

14. Up To Date. Coronavirus disease 2019 (COVID-19); 2020. Available from: https://www.uptodate.com/contents/ coronavirus-disease-2019-covid-19\#H2325386707 [Last accessed on 11 Mar 2020]

15. Shahid Ud Din Wani, Gautam SP, Qadrie ZL. An overview on covid-19: clinical features, treatment and prevention. Coronaviruses 2020;1-5. https://doi.org/10.2174/ 2666796701999200818145609

16. Lippi G, Simundic AM, Plebani M. Potential preanalytical and analytical vulnerabilities in the laboratory diagnosis of coronavirus disease 2019 (COVID-19). Clin Chem Lab Med 2020;58:1070-6.

17. Lagier JC, Colson P, Tissot Dupont H, Salomon J, Doudier B, Aubry C, et al. Testing the repatriated for SARS-Cov2: should laboratory-based quarantine replace traditional quarantine? Travel Med Infect Dis 2020;34:101624.

18. Gennaro FD, Pizzol D, Marotta C. Coronavirus diseases (COVID19) current status and future perspectives: a narrative review. Int I Environ Res Public Health 2020;17:1-12.

19. Won J, Lee S, Park M, Kim TY, Park MG, Choi BY, et al. Development of a laboratory-safe and low-cost detection protocol for SARS-CoV-2 of the coronavirus disease 2019 (COVID-19). Exp Neurobiol 2020;29:107-19.

20. World Health Organization. Coronavirus disease (COVID-19) technical guidance: laboratory testing for 2019-nCoV in humans. Available from: https://www.who.int/emergencies/ diseases/novel-coronavirus-2019/technical guidance/laboratory-guidance [Last accessed on 31 Mar 2020]

21. Wang Z, Chen X, Lu Y, Chen F, Zhang W. Clinical characteristics and therapeutic procedure for four cases with 2019 novel coronavirus pneumonia receiving combined Chinese and Western medicine treatment. Biosci Trends 2020;14:64-8.

22. Young BE, Ong SWX, Kalimuddin S, Low JG, Tan YS, Loh J. Epidemiologic features and clinical course of patients infected with SARS-CoV-2 in singapore. JAMA 2020;323:1488-94. 
23. $\mathrm{Lu} \mathrm{H}$. Drug treatment options for the 2019-new coronavirus (2019-nCoV). Biosci Trends 2020;14:69-71.

24. National Institutes of Health (2020) Novel coronavirus structure reveals targets for vaccines and treatments. Available from https://www.nih.gov/news-events/nihresearch-matters/ novelcoronavirus-structure-reveals-targets-vaccines-treatments [Last accessed on 11 Mar 2020]

25. Russell CD, Millar JE, Baillie JK. Clinical evidence does not support corticosteroid treatment for 2019-nCoV lung injury. Lancet 2020;395:473-5.

26. Arabi Y, Mandourah Y, Al-Hameed F, Sindi AA, Almekhlafi GA, Hussein MA, et al. Corticosteroid therapy for critically ill patients with middle east respiratory syndrome. Am J Respir Crit Care Med 2018;197:757-67.

27. Yang X, Yu Y, Xu J, Shu H, Xia J, Liu H, et al. Clinical course and outcomes of critically ill patients with SARS-CoV-2 pneumonia in Wuhan, China: a single-centered, retrospective, observational study. Lancet Respir Med 2020;2600:1-7.

28. Rochwerg B, Brochard L, Elliott MW, Hess D, Hill NS, Nava S, et al. Official ERS/ATS clinical practice guidelines: noninvasive ventilation for acute respiratory failure. Eur Respir J 2017;50. DOI:10.1183/13993003.02426-2016
29. Centers for Disease Control and Prevention. Coronavirus disease 2019 (COVID-19)-how to protect yourself 2020 Available from: https://www.cdc.gov/coronavirus/2019ncov/about/prevention.html [Last accessed on 11 Mar 2020]

30. Lim J, Jeon S, Shin HY, Kim MJ, Seong YM, Lee WJ, et al. Case of the index patient who caused tertiary transmission of COVID-19 infection in korea: the application of lopinavir/ritonavir for the treatment of covid-19 infected pneumonia monitored by quantitative RT-PCR. J Korean Med Sci 2020;35:e79.

31. Adhikari SP, Meng S, Wu YJ, Mao YP, Ye RX, Wang QZ, et al. Epidemiology, causes, clinical manifestation and diagnosis, prevention and control of coronavirus disease (COVID-19) during the early outbreak period: a scoping review. Infect Dis Poverty 2020;9:29.

32. Centers for Disease Control and Prevention 2019 Novel Coronavirus, Wuhan, China; 2020. Available from: https://www.cdc.gov/coronavirus/2019-ncov/preventgetting-sick/prevention.html [Last accessed on 13 Apr 2020]

33. El Bcheraoui C, Mimche H, Miangotar Y, Krish VS, Ziegeweid F, Krohn KJ, et al. Burden of disease in francophone Africa, 19902017: a systematic analysis for the global burden of disease study 2017. Lancet Glob Health 2020;8:e341-e351. 